\section{JURNAL ABDIMAS

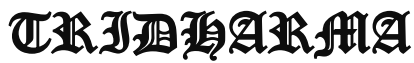

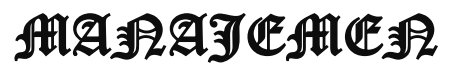

P-ISSN 2615-6849, E-ISSN 2716-070X

Jurnal ABDIMAS Vol. 2,No.3, Agustus 2021,Hal(26-32)

@Prodi Manajemen Fakultas Ekonomi Universitas Pamulang

Email: abdimasjurnal.unpam@gmail.com Telp: (021) 741-2566

\title{
PELATIHAN BERBASIS ONLINE DI ERA COVID -19
}

\author{
Veta Lidya Delimah Pasaribu ,Daniel bagus saputra lumbang tobing, \\ Angga firdaus, agil setiawan, sonya mutiara vida, hakki rizki mustakim. \\ Dosen Dan Mahasiswa prodi manajemen fakultas ekonomi \\ Universitas pamulang

\begin{abstract}
Email : dosen01890@unpam.ac.id,Danieltobing234@gmail.com, Sonyamutiara60@gmail.com, Anggafirdauz19@gmail.com, agilsetiawan51@gmail.com, hakkr53@gmail.com,
\end{abstract}

\begin{abstract}
ABSTRAK
Tujuan dari kegiatan Pengabdian Kepada Masyarakat ini adalah untuk melaksanakan salah satu Tri Dharma Perguruan Tinggi. Selain itu, melalui kegiatan Pengabdian Kepada Masyarakat ini, keberadaan perguruan tinggi diharapkan dapat memberikan pemahaman dan penerapan mengenai pemanfaatan sebagai media untuk meneruskan kegiatan yang tidak dapat dilakukan secara tatap muka selama pandemi COVID-19.

Metode kegiatan yang digunakan adalah tim pelaksana mengunjungi yang beralamat di kelurahan pamulang barat jl.surya kencana no 1 pamulang, Tangerang Selatan dan memberikan pelatihan pada Hari senin 23 maret 2021. Pelatihan ini bertujuan agar karyawan dapat memahami pentingnya peran teknologi di era covid-19 untuk mempermudah jalannya pekerjaan.

Hasil yang diperoleh dari penelitian ini karyawan memanfaatkan teknologi i untuk kegiatan Work From Home, Disimpulkan bahwa memanfaatkan teknologi untuk tetap melaksanakan kegiatan karena fasilitas dan fitur dari teknologi yang memiliki keunggulan dan kemudahan untuk dipergunakan oleh berbagai kalangan kariyawan.
\end{abstract}

Kata kunci : Pelatihan berbasis online, kinerja kariawan.

\section{ABSTRACT}

The purpose of this Community Service activity is to carry out one of the Tri Dharma Perguruan Tinggi. In addition, through this Community Service activity, the existence of universities is expected to provide understanding and application of use as a medium to continue activities that cannot be carried out face-to-face during the COVID-19 pandemic.

The activity method used was the implementation team visiting kelurahan pamulang barat jl.surya kencana no 1 pamulang, Tangerang Selatan and provided training on Saturday, March 20, 2021. This training aims to make employees understand the important role of technology in the Covid-19 era to facilitate work.

The results obtained from this study, employees use technology i for Work From Home activities. It is concluded that using technology to continue carrying out activities because the facilities and features of technology have advantages and ease for use by various career groups.

Keywords: 3M Implementation, Employee Performance. 


\section{JURNAL ABDIMAS

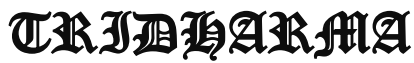

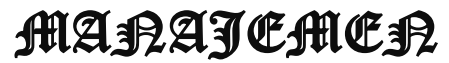

P-ISSN 2615-6849, E-ISSN 2716-070X

Jurnal ABDIMAS Vol. 2,No.3, Agustus 2021,Hal(26-32)

@Prodi Manajemen Fakultas Ekonomi Universitas Pamulang

Email: abdimasjurnal.unpam@gmail.com Telp: (021) 741-2566

\section{PENDAHULUAN}

Perkembangan teknologi pada zaman era modern ini sangatlah pesat, saat ini teknologi telah memberikan banyak manfaat dalam kemajuan diberbagai aspek. Perkembangan itu bukan hanya dalam hitungan tahun, bulan, atau hari, melainkan jam, bahkan menit atau detik terutama berkaitan dengan teknologi informasi dan komunikasi yang ditunjang dengan teknologi elektronika. Penggunaan teknologi oleh manusia dalam membantu menyelesaikan pekerjaan merupakan hal yang menjadi keharusan dalam kehidupan. Perkembangan teknologi ini juga harus diikuti dengan perkembangan pada Sumber Daya Manusia (SDM).

Manusia sebagai pengguna teknologi harus mampu memanfaatkan teknologi yang ada saat ini, maupun perkembangan teknologi tersebut selanjutnya. Adaptasi manusia dengan teknologi baru yang telah berkembangBerbagai pelanggaran terhadap penerapan protokol kesehatan memang masih terjadi di berbagai wilayah, walaupun razia sering dilakukan petugas. Sanksi yang diberikan belum mampu membangkitkan kesadaran warga untuk mematuhi aturan. Ketidakpatuhan ini yang membuat penularan virus semakin cepat meluas, tidak hanya meningkatkan jumlah pasien positif yang memenuhi ruangan rumah sakit, namun juga menambah jumlah korban yang wafat. Ketidakpatuhan warga seolah menjadi pemandangan keseharian, yang dianggap hal biasa terjadi di lingkungan masya rakat. Padahal, ketidakpatuhan warga adalah kunci bagi kegagalan penanganan pandemi COVID-19.

Pandemi Covid-19 yang menyerang hampir seluruh negara di dunia dinilai merugikan banyak pihak, salah satunya dalam sektor ekonomi. Bank Dunia pada Juni 2020 pun telah memprediksi akan terjadi penurunan pertumbuhan ekonomi hingga 5,2 persen akibat pandemi pada tahun ini.
Demi memitigasi hal tersebut, banyak negara telah melakukan percepatan transformasi digital. Hal ini dilakukan untuk membantu pengusaha beradaptasi dengan perubahan pola kebiasaan konsumen agar bisnis dapat tetap berjalan.Disadari atau tidak, peran teknologi sudah sangat membantu masyarakat dalam melakukan pencegahan virus corona. Perkembangan teknologi yang semakin maju dinilai memiliki dampak positif dalam menghambat penyebaran virus corona. jika melihat angka-angka statistik jumlah penularannya, peran teknologi tidak akan terasa.

Namun bayangkan jika tidak ada bantuan teknologi sejak awal virus ini muncul. Korban yang berjatuhan bisa lebih banyak dari saat ini.Beberapa negara pun mulai menerapkan protokol covid-19 sesuai dengan aturan pemerintah salah satunya melakukan penerapan Pembatasan Sosial Berskala Besar (PSBB) hingga lockdown. Sebagai akibatnya banyak kantor yang melakukan Working From Home (WFH) atau bekerja dari rumah.

Dengan pemberlakuan work from home (WFH) di banyak perusahaan, manajemen membutuhkan sistem yang dapat membantu seluruh tim berkoordinasi guna memastikan operasional bisa berjalan dengan baik. Kendati demikian, untuk memulai transformasi digital dibutuhkan pula waktu dan sumber daya manusia yang tidak sedikit. Belum lagi ada risiko kegagalan dalam mengembangkan sistem.

kelurahan pamulang barat jl.surya kencana no 1 pamulang, Tangerang Selatan merupakan salah satu kelurahan di Tangerang Selatan

Hasil survey yang telah dilakukan terhadap beberapa karyawan perkantoran di kelurahan pamulang barat bahwa belum melakukan teknologi secara menyeluruh, sehingga mayoritas karyawan melakukan 


\section{JURNAL ABDIMAS

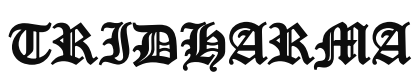 \\ AIA:}

pekerjaan dikantor dengan berbagai macam resiko dari covid-19, kendati demikian untuk mengurangi resiko-resiko yang terjadi pada era Covid-19 ini Teknologi juga berperan baik untuk meminimalisir kesalahan-kesalahan dalam bekerja.

\section{RUMUSAN MASALAH}

Ditengah masa pandemi Covid 19 ini muncul sebuah aturan terutama di Indonesia yang dimana masyarakat Indonesia di haruskan untuk menjaga jarak antara satu dengan yang lain minimal satu setengah meter sehingga masyarakat Indonesia dipaksa untuk stay at home / dirumah saja dan melakukan seluruh aktivitas dari rumah seperti berkerja dari rumah, belajar dari rumah dan ibadah dari rumah.

Salah satu persoalan yang dihadapi oleh kelurahan pamulang batrat adalah kurangnya penggunaan teknologi Sehingga memicu penyebaran resiko covid19, pasalnya Teknologi membantu meminimalisir kesalahan-kesalahan dalam bekerja juga membantu meminimalisir penyebaran virus covid-19.Berkumpul di dalam ruangan dengan kumpulan orang dalam jumlah banyak dan durasi cukup lama berpotensi tinggi terjadi penularan virus corona. Satu saja karyawan yang terinfeksi maka mudah menyebarkan kepada yang lain.

Di seluruh dunia jutaan orang telah meninggalkan kantor menyusul instruksi pemerintah agar karyawan bekerja dari rumah. Hal ini dikarenakan orangorang yang menghabiskan keseharian mereka dikantor dimana ruang bersama dan interaksi tinggi dapat menyebarkan virus apapun yang mereka miliki termasuk virus COVID-19.

Bekerja dari rumah (work from home) adalah suatu pilihan di era pandemi COVID-19. Work from home telah mengubah sistem kerja yaitu melakukan pelayanan kepada public melalui daring (online). Sistem daring (online) dilakukan untuk mengimplementasikan protocol pencegahan COVID-19 yang dikeluarkan oleh pemerintah. Pengunaan Teknologi merupakan salah satu cara yang bisa dimanfaatkan untuk work from home saat social distancing untuk mencegah penyebaran virus COVID-19.

Di era Covid-19 ini penggunaan Teknologi tidak hanya membantu untuk merampingkan proses, tetapi juga mencegah banyak kesalahan dan memastikan setiap hal yang dijalankan dalam proses dilakukan jauh lebih cepat. Bahkan dengan semua kemajuan ini, ternyata masih ada kebutuhan besar bagi karyawan untuk melakukan banyak pekerjaan dalam fasilitas manufaktur. Para karyawan yang melakukan pekerjaannya untuk menjaga dan mengabarkan bahwa setiap proses berjalan dengan baik. Namun, tetap saja kesalahan yang disebabkan oleh manusia ( human error ) masih terjadi.

Kesalahan yang terjadi karena kesalahan manusia memang menjadi suatu permasalahan yang selalu ada dalam setiap proses. Meskipun kesalahan kesalahan manusia tidak bisa langsung dihilangkan, namun ada beberapa cara yang bisa dilakukan untuk mempernaiki kesalahan tersebut.

\section{TUJUAN KEGIATAN}

Kegiatan Pengabdian Masyarakat ini bertujuan untuk pemanfaatan teknologi dalam kegiatan kerja dalam perusahaan. Pemanfaatan teknologi ini bertujuan untuk meminimalisir kesalahan-kesalahan dalam pelaksanaan kerja juga mempermudah kegiatan bekerja dari jarak jauh. Pada implementasinya, pemanfaatan teknologi ini dapat membantu karyawan dan juga dapat berpengaruh baik pada perusahaan . 


\section{JURNAL ABDIMAS

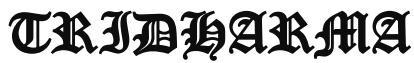

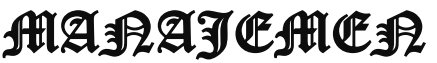

P-ISSN 2615-6849, E-ISSN 2716-070X

Jurnal ABDIMAS Vol. 2,No.3, Agustus 2021,Hal(26-32)

@ Prodi Manajemen Fakultas Ekonomi Universitas Pamulang

Email: abdimasjurnal.unpam@gmail.com Telp: (021) 741-2566

\section{TINJAUAN PUSTAKA}

Perkembangan teknologi di Era sekarang ini sangat pesat. Berbagai kemajuan teknologi dapat kita peroleh dengan mudahnya bahkan informasi menjadi salah satu kebutuhan pokok disamping kebutuhan akan sandang, pangan dan papan. Pemanfaatan teknologi informasi memiliki dampak positif seperti mempermudah komunikasi jarak jauh, mempermudah memperoleh informasi,mempermudah pekerjaan manusia. Hampir semua aktivitas organisasi saat ini telah dimasuki oleh aplikasi teknologi informasi. Teknologi informasi dapat didefinisikan sebagai perpaduan antara teknologi komputer dan telekomunikasi dengan teknologi lainnya seperti perangkat keras, perangkat lunak, database, teknologi jaringan, dan peralatan telekomunikasi lainnya. Selanjutnya, teknologi informasi dipakai dalam sistem informasi organisasi untuk menyediakan informasi bagi para pemakai dalam rangka pengambilan keputusan (Maharsi, 2000). Perkembangan teknologi informasi yang sangat pesat telah menjadi pendukung utama untuk memperoleh informasi dengan cara mudah dan cepat, terlebih lagi dengan adanya internet.

Di era pandemi covid-19 Teknologi berperan aktif dan dapat meringankan pekerjaan ataupun tugas lainya dalam jangka waktu yang tepat dan cepat.

\section{1) Pentingnya Teknologi dalam bekerja}

Mengubah proses manual menjadi otomatis, sehingga dapat mengurangi biaya untuk tenaga kerja, biaya untuk kertas, alat tulis, dan lain sebagainya. Waktu yang diperlukan untuk mengerjakan suatu tugas pekerjaan menjadi lebih cepat dengan adanya teknologi.

\section{Manfaat Teknologi}

1. Pekerjaan jadi cepat selasai

2. Link semakin luas

3. Bekerja jadi lebih semangat

4. Dapat belajar hal baru

\section{METODE PELAKSANAAN}

Metode kegiatan pengabdian kepada masyarakat ini dibagi menjadi beberapa tahap. Tahap pertama adalah identifikasi masalah yang dilakukan sebagai langkah awal untuk merumuskan apa saja yang akan dijadikan bahan untuk perancangan sistem dan materi pelatihan dalam kegiatan pengabdian kepada masyarakat ini.

Tahap berikutnya yaitu melaku kan survei lapangan kelurahan pamulang barat jl.surya kencana no 1 pamulang, Tangerang Selatan Proses pelatihan ini membahas mengenai tentang pentingnyaperan teknologi di era covid-19 untuk mempermudah jalannya pekerjaan.

Pada tahap ini anggota tim pelaksana berdiskusi sesuai tema dan materi yang akan disampaikan, bahan dan alat yang diperlukan, serta persiapan teknis lainnya yang dibutuhkan untuk kelancaran pelaksanaan kegiatan pengabdian kepada masyarakat ini. Permasalahan yang ditemukan pada karyawan kelurahan pamulang barat ini yaitu kurangnya pemahaman dan penerapan mengenai pemanfaatan teknologi sebagai media untuk meneruskan kegiatan yang tidak dapat dilakukan secara tatap muka selama pandemi COVID-19.

Tahap terakhir dalam kegiatan pengabdian kepada masyarakat ini yaitu tindak lanjut dari pelaksanaan kegiatan ini. Pada tahap ini dilakukan diskusi atau tanya 


\section{JURNAL ABDIMAS

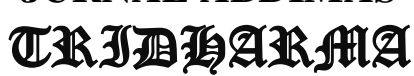 AIA:}

jawab tentang permasalahan seputar pentingnyaperan teknologi di era covid-19 untuk mempermudah jalannya pekerjaan.

\section{HASIL DAN PEMBAHASAN Hasil Kegiatan}

Berdasarkan hasil sosialisasi, tanya jawab dan pengamatan langsung selama kegiatan berlangsung,kegiatan pengabdian pada masyarakat ini memberikan hasil sebagai berikut.

Penggunaan teknologi informasi dan komunikasi saat Work From Home Peran Teknologi Bagi karyawan yang Beraktifitas Dirumah

Penggunaan teknologi informasi dan komunikasi untuk kepentingan medis

\section{B. Faktor Pendukung dan Faktor Penghambat}

Beberapa faktor yang mendukung terlaksananya kegiatan pengabdian pada masyarakat ini adalah besarnya minat dan antusiasme peserta selama kegiatan, sehingga kegiatan berlangsung dengan lancar dan efektif. Sedangkan faktor penghambatnya adalah keterbatasan waktu pelatihan dan fasilitas peralatan yang masih minim. Namun demikian dari sisi lain, ada tantangan lain yang muncul dari penerapan WFH, yakni terkait persetujuan dari sebuah kesepakatan.Biasanya, persetujuan membutuhkan tanda tangan sebagai bukti kesepakatan. Oleh karena itu, operasional perusahaan secara jarak jauh ini membutuhkan teknologi digital signature atau tanda tangan digital.

Di dalam tanda tangan digital, terdapat kunci publik dan kunci privat yang dikeluarkan oleh sebuah badan yang bernama Certification Authority (CA). Kedua kunci ini mengoptimalkan tingkat keamanan dengan meniadakan resiko pemalsuan dokumen dan tanda tangan, serta meminimalisir dokumen rusak dan hilang.

\section{KESIMPULAN DAN SARAN}

\section{Kesimpulan}

Dari kegiatan pengabdian pada masyarakat ini dapat disimpulkan bahwa:

Teknologi Informasi akan terus berkembang seiring dengan jumlah pemakai internet yang pesat. Berdasarkan laporan terbaru We Are Social (2020), menyatakan bahwa ada 175,4 juta pengguna internet di Indonesia. Ini membuktikan bahwa ada peningkatan $17 \%$ atau 25 juta pengguna internet di negeri ini. Berdasarkan total populasi Indonesia yang berjumlah 272,1 juta jiwa, maka itu artinya 64\% setengah penduduk RI telah merasakan akses internet. Berdasarkan hasil analisa kualitatif, pengamatan langsung, internet telah menjadi media yang memberikan informasi ke masyarakat tentang bahaya dan upaya pencegahan Covid 19. Akan tetapi tidak dipugkiri bahwa teknologi informasi sangat dibutuhkan dikala wabah virus covid-19 sekarang. Karena demikian, itulah peranan teknologi informasi sangat penting dizaman dimana pengguna internet sudah meluas di berbagai negara.

Banyak dari masyarakat menerima begitu saja teknologi digital modern yang bahkan tidak dapat diakses beberapa dekade lalu. Inovasi-inovasi teknologi ini, yang telah lama ditandai sebagai hal sepele, tidak penting, atau bahkan berbahaya selama masa tenang kini menjadi sangat diperlukan dalam menghadapi pandemi COVID-19. Sekarang telah ada berbagai teknologi digital yang dapat digunakan untuk menambah dan meningkatkan strategi pekerjaan, pembelajaraan dan kesehatan masyarakat. Selama pandemi COVID19, teknologi memainkan peran penting dalam menjaga kegiatan 


\section{JURNAL ABDIMAS

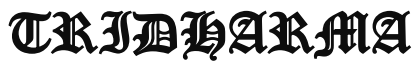 \\ AtA:}

masyarakat tetap berfungsi pada saat Pembatasan Sosial Berskala Besar (PSBB).

\section{Saran}

Adapun saran yang dari kegiatan ini perlu dilakukan lagi lanjutan kegiatan untuk pendalaman materi. Dikarenakan waktu yang singkat. Seperti pelunya pembelajaran pemanfaatan media-media interaktif yang meningkatkan semangat karyawan untuk bekerja

\section{Ucapan Terima Kasih}

Puji Syukur kami panjatkan kehadirat Allah SWT, karena telah memberikan rahmatNya sehingga kami dapat menyelesaikan kegiatan Pengabdian Kepada Masyarakat (PKM) dengan baik. Terimakasih juga kami ucapkan kepada Rektor Universitas Pamulang, Dekan Fakultas Ekonomi Universitas Pamulang, Ketua Program Studi Manajemen S-1 Universitas Pamulang, Ketua LPPM Universitas Pamulang, Ketua Taman Bacaan Perigi Jl. Pahlawan Rt. 04 Rw. 07 Keduang Kec. Sawangan Kab. Depok dan semua pihak yang telah berkontribusi dengan memberikan masukan sehingga laporan akhir ini dapat kami selesaikan. Kami menyadari PKM ini masih jauh dari kata sempurna dan masih banyak kekurangan oleh karena itu kami mohon saran dan kritiknya untuk pengembangan PKM selanjutnya. Dengan segala kerendahan hati kami juga berharap semoga hasil PKM ini dapat bermanfaat sebagai sumbangan pemikiran bagi masyarakat serta praktisi maupun akademisi

\section{DAFTAR PUSTAKA}

Starkey, L. (2020). A review of research exploring teacher preparation for the digital age. Cambridge
Journal of Education, 50 1, 3756.

Jessica Li, Rajashi Ghosh \& Stefanos Nachmias (2020) In a time of COVID-19 pandemic, stay healthy, connected, productive, and learning: words from the editorial team of HRDI, Human Resource Development International, 23:3， 199-207, DOI: 10.1080/13678868.2020.175249 3

Almarzooq, Zaid \& Lopes, Mathew \& Kochar, Ajar. (2020). Virtual Learning during the COVID-19 Pandemic: A Disruptive Technology in Graduate Medical Education. Journal of the American College of Cardiology. 10.1016/j.jacc.2020.04.015.

Ali Sadikin \& Afreni Hamidah.2020.Pembelajaran daring ditengah wabah covid-19.Jurnal Ilmiah Pendidikan Biologi. Vol No 2 hal 214-224

Ely Satiyasih Rosali.2020. Aktivitas Pembelajaran daring pada masa pandemi covid-19 pendidikan geografi universitas siliwangi tasikmalaya.Geography science journal (GEOSEE) Vol No 1

Pasaribu, V. L. D., Agrasadya, A., Shabrina, N., \& Krisnaldy, K. (2020). Menjadi Enterpreneur Muda Yang Memiliki Jiwa Leadership Untuk Menghadapi Masa Depan. Abdi Laksana: Jurnal Pengabdian Kepada Masyarakat, 1(1). 


\section{JURNAL ABDIMAS

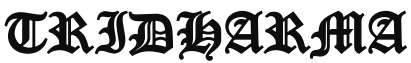

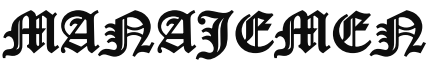

P-ISSN 2615-6849, E-ISSN 2716-070X

Jurnal ABDIMAS Vol. 2,No.3, Agustus 2021,Hal(26-32)

@ Prodi Manajemen Fakultas Ekonomi Universitas Pamulang

Email: abdimasjurnal.unpam@ gmail.com Telp: (021) 741-2566

SAWAH BARU CIPUTAT, TANGERANG SELATAN. Abdi

Laksana: Jurnal Pengabdian

Kepada Masyarakat, 2(2), 295-

301.

Pasaribu, V. L. D., Susanti, F., \& Hartuti, E. T. K. (2019). Memotivasi Siswa dan Siswi SMK Letris Indonesia di Dalam Menentukan Pilihan Untuk Melanjutkan Pendidikan Atau Bekerja Setelah Lulus Sekolah. Jurnal Pengabdian Dharma Laksana, 1(2), 161-172.

Pasaribu, V. L. D., Sulaiman, S., Sutiman, S., Thaharudin, T., \& Purnomo, B. Y. (2020). Pengenalan Letak Posyandu Terdekat Dikelurahan Pisangan Dengan Manajemen Pemasaran Revolusi 4.0 Untuk Meningkatkan Pengetahuan Masyarakat Letak Dan Fungsi Posyandu Terdekat Pada Kelurahan Pisangan. Dedikasi Pkm, 1(1), 105-110.

Pasaribu, V. L. D., Oktrima, B., Prabowo, B., Arianto, N., \& Haryoko, U. B. (2020). Progam Pendampingan Dan Penyelenggaraan Pendidikan Anak Pada Usia Dini Terhadap Prestasi Belajar Dilingkungan Rt 020 Rw 009. Kel Giri Peni. Kec Wates. Yogyakarta. Jurnal Lokabmas Kreatif, 1(1), 71-75.

Pasaribu, V. L. D., Jannah, M., Fazar, M., Putra, S. P., Monalisa, M., \& Sofa, M. (2021). MENINGKATKAN PRODUKTIVITAS USAHA DIMASA PANDEMI PADA IBU PKK RT 004/003 KELURAHAN
Pasaribu, V. L. D., Yuniati, H. L., Pranata, R., Sembayu, R., Purba, S. M., \& Nurbayani, T. T. A. (2021). MANAJEMEN KEUANGAN UNTUK MENGHADAPI DAN BERTAHAN DI ERA COVID 19. Jurnal Abdimas Tri Dharma Manajemen, 2(2), 12-18.

Pasaribu, V. L. D., Dwiyatni, A., Sabina, C., Ridwan, M., Gunawan, D. D., \& Noviani, B. C. (2021). EVALUASI PENERAPAN 3M DIMASA PANDEMIC COVID 19. Jurnal Abdimas Tri Dharma Manajemen, 2(2), 54-60.

Pasaribu, V. L. D., Syafei, A. N., Farhan, A., Aufaizah, A., Irani, C., \& Firtiayani, S. R. (2021). PENGARUH DISPLIN PROTOKOL KESEHATAN TERHADAP PENCEGAHAN PENULARAN VIRUS COVID19. Jurnal Abdimas Tri Dharma Manajemen, 2(2), 91-98.

Pasaribu, V. L. D., Septiani, F., Rahayu, S., Lismiatun, L., Arief, M., Juanda, A., ... \& Rahim, R. (2021). Forecast Analysis of Gross Regional Domestic Product based on the Linear Regression Algorithm Technique.

Priadi, A., Pasaribu, V. L. D., Virby, S., Sairin, S., \& Wardani, W. G. 


\section{JURNAL ABDIMAS

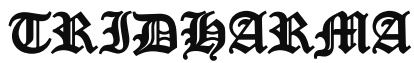

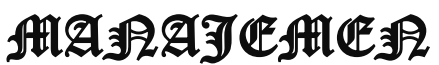

P-ISSN 2615-6849, E-ISSN 2716-070X

Jurnal ABDIMAS Vol. 2,No.3, Agustus 2021,Hal(26-32)

@ Prodi Manajemen Fakultas Ekonomi Universitas Pamulang

Email: abdimasjurnal.unpam@ gmail.com Telp: (021) 741-2566
(2020). Penguatan Ekonomi

Kreatif Berbasis Sumber Daya

Desa Dikelurahan Rempoa. Abdi

Laksana: Jurnal Pengabdian

Kepada Masyarakat, 1(3), 356-35

\section{FOTO KEGIATAN}
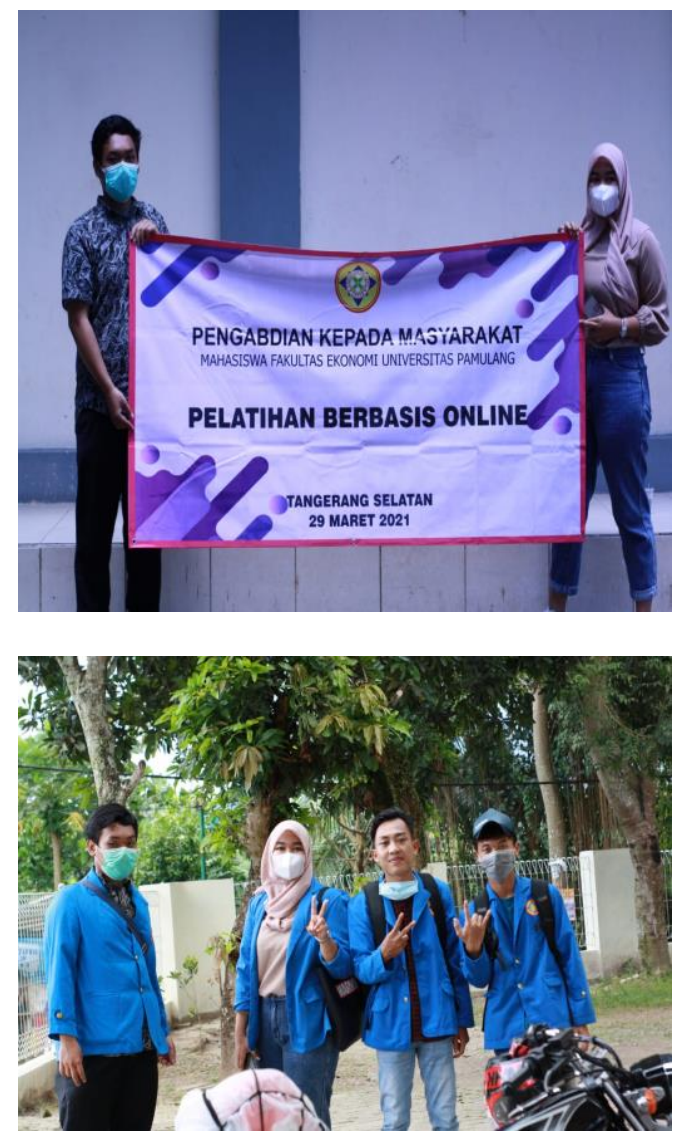

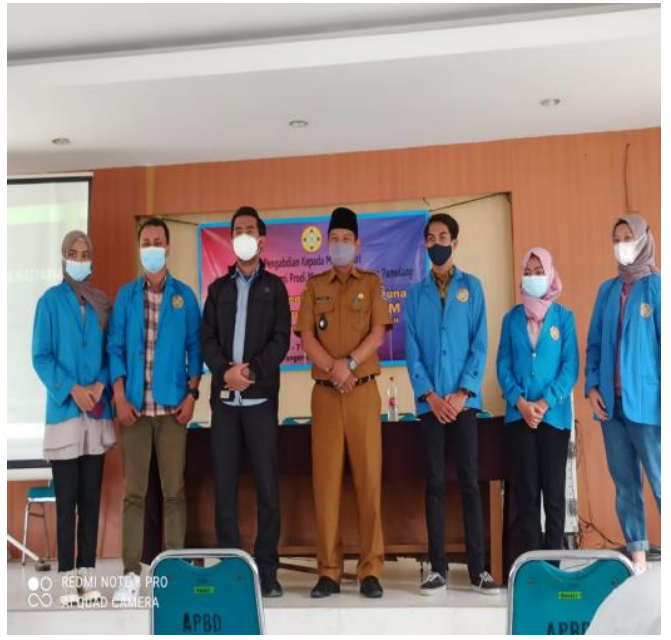

